\title{
Education: We Must Keep Our Promise
}

\author{
Sjur Bergan
}

Describing the promise of Education for the future could be done very summarily: without education, no future - or at least not one worth waiting for. While true, this summary description is nevertheless unsatisfactory. It does not say why education is crucial, and what the role of higher education should be.

Promises are made to be fulfilled, and to do so, we must spell out what the promise of education is. As I see it, the promise is composed of four parts, which correspond to the purposes of higher education:

- Preparation for sustainable employment;

- Preparation for life as active citizens in democratic societies;

- Personal development;

- The development and maintenance of a broad, advanced knowledge base (Bergan 2005; Council of Europe 2007).

It is encouraging to see that the unilateral focus on educating for the labour market that was often seen in the early 2000s is giving way to a broader view of the societal importance of education. In Europe, this is reflected in the priorities and ministerial communiqués of the Bologna Process starting with the 2007 London Communiqué and culminating in the Yerevan and Paris Communiqués Bologna Process 2007, 2015, 2018. In the United States, this development is reflected in the work of the International Consortium for Higher Education, Civic Responsibility and Democracy (n.d.) and the Anchor Institutions Task Force (n.d.). Globally, the IAU plays a vital role through its commitment to education and research for sustainable development, its commitment to values-based higher education, its work to enhance capacities and commitment to the broader mission of higher education on all continents, and now also by bringing a global perspective to the work the Council of Europe and the

\footnotetext{
S. Bergan $(\bowtie)$

Council of Europe, Strasbourg, France

e-mail: sjur.bergan@coe.int 
International Consortium are doing on the democratic mission of higher education (Council of Europe, n.d.).

One and the same competence can be relevant to several purposes of education. Analytical abilities, critical thinking skills, and language competences all strengthen our possibilities on the labour market. They also make us better suited to helping develop our societies and contribute to our personal development, and we cannot do serious research without them.

That many of the jobs today's students will compete for in a decade do not yet exist, is a truism, but this should not lead to the conclusion that higher education institutions cannot prepare their students for them. Higher education should not aim to prepare for very specific jobs but rather provide subject-specific and generic competences that prepare for a whole range of jobs and that encourage students to continue learning after graduation. Perhaps more importantly, higher education should not see the labour market as something that evolves and that they just have to adapt to. Higher education should influence the labour market by developing new knowledge and understanding that can be put to innovative use in creating new jobs. Information technology would not have been omnipresent if higher education had not played its part.

What is true for the development of the labour market is even more true for the development of society. Higher education must help shape our society, not just sit back and observe it develop (Harkavy et al. 2020). This is an issue of knowledge and understanding but also of ethics and values. Knowing and being able to do something without considering the consequences should not be what higher education teaches and students learn. Therefore, the traditional definition of learning outcomes as what the learner knows, understands, and is able to do is inadequate. The definition must comprise not only what learners are able to do but also what they are willing to do, and by implication what they are willing to abstain from doing for ethical reasons. Being able to alter plants or animals genetically may be a matter of technical competence, but decision on whether we should do so draws on our ethical competence. Subjectspecific and generic competences must be developed together.

History shows that the forms of democracy are insufficient. Parliaments, constitutions, and elections cannot be democratic unless they build on a culture of democracy: a set of attitudes and behaviours that accept, inter alia, that while majorities decide, minorities have inalienable rights, that conflicts need to be resolved peacefully through dialogue, and that diversity is a strength rather than a threat. A culture of democracy requires competences for democratic culture (Council of Europe 2018a, b, c), and higher education must help develop them.

The technical complexity of modern societies makes advanced competences more important for more people than ever before. Here, higher education has largely done its job: it has trained more highly qualified subject specialists than at any other time in our history. I am less convinced, though, that higher education has fulfilled another part of its mission: educating intellectuals, by which I mean graduates who are able and willing to put their advanced subject-specific competences in a broader context, ask the difficult questions we face as societies, and find ethically sound answers to those questions. 
To fulfil its promise, higher education must fulfil all its major purposes. It must educate students that are technically competent, intellectually curious, and endowed with a sense of ethical and societal responsibility. Its research must be guided by concern for our societies. To fulfil its promise, higher education must not wait for the future to arrive-it must shape the future and help develop societies worth living in. To fulfil its promise, higher education must deliver knowledge and understanding. It must also deliver the ethical compass we need to navigate the future.

To fulfil its promise, the IAU must continue to develop a sustainable and responsible higher education on a global scale. The IAU must persuade higher education to be brave, independent, and committed. It must help defend higher education against governments that see critical analysis, academic freedom, and institutional autonomy as a threat.

If the first seven decades of the IAU can be used as an indicator, there is every reason to be hopeful that the IAU will continue to be a guide on the way to democratic sustainable societies built on knowledge and understanding, ethics, and societal responsibility in the decades and even centuries to come.

\section{References}

Anchor Institutions Task Force (AITF) (n.d.), Strategic Plan 2020-2023, Retrieved from: https:// www.margainc.com/aitf/ (24.04.2020)

Bergan, S. (2005). "Higher Education as a "Public Good and a Public Responsibility": What Does it Mean?". In L. Weber \& S. Bergan (Eds.), The Public Responsibility for Higher Education and Research Strasbourg: Council of Europe Publishing -Council of Europe Higher Education Series No. 2: $13-28$

Bologna Process (2007): "European Higher Education in a Global Setting. A Strategy for the External Dimension of the Bologna Process", Retrieved from: http://www.ehea.info/media.ehea. info/file/2007_London/35/4/2007_London_Strategy-for-EHEA-in-global-setting_581354.pdf (24.04.2020)

Bologna Process (2015): "Yerevan Communiqué", Retrieved from: http://www.ehea.info/media. ehea.info/file/2015_Yerevan/70/7/YerevanCommuniqueFinal_613707.pdf (24.04.2020)

Bologna Process (2018): "Paris Communiqué. Paris, 25th May 2018, Retrieved from: http://www. ehea.info/Upload/document/ministerial_declarations/EHEAParis2018_Communique_final_ 952771.pdf (24.04.2020)

Council of Europe (n.d.). The Democratic Mission of Higher Education, Retrieved from: https://www.coe.int/en/web/higher-education-and-research/democratic-mission-of-highereducation (24.04.2020)

Council of Europe (2007): Recommendation Rec (2007) 6 of the Committee of Ministers to member states on the Public Responsibility for Higher Education and Research, Retrieved from: https:// search.coe.int/cm/Pages/result_details.aspx?ObjectId=09000016805d5dae (24.04.2020).

Council of Europe (2018a): Reference Framework of Competences for Democratic Culture, Volume 1, Context, concepts and model, Retrieved from: https://www.coe.int/en/web/referenceframework-of-competences-for-democratic-culture/context-concepts-and-model (24.04.2020)

Council of Europe (2018b): Reference Framework of Competences for Democratic Culture, Volume 2, Descriptors, Retrieved from: https://www.coe.int/en/web/reference-framework-ofcompetences-for-democratic-culture/descriptors-of-competences (24.04.2020) 
Council of Europe (2018c): Reference Framework of Competences for Democratic Culture, Volume 3, Guidance documents, Retrieved from: https://www.coe.int/en/web/reference-framework-ofcompetences-for-democratic-culture/guidance-for-implementation (24.04.2020)

Harkavy, Ira; Sjur Bergan; Tony Gallagher; Hilligje van't Land (2020): “Universities must help shape the post-COVID-19 world", in University World News April 19, 2020, Retrieved from: https://www.universityworldnews.com/post.php?story=20200413152542750 (24.04.2020)

International Consortium for Higher Education, Civic Responsibility and Democracy (n.d.), Introduction, Retrieved from: http://www.internationalconsortium.org/, (24.04.2020)

Sjur Bergan is Head of the Education Department of the Council of Europe and leads its projects on Competences for Democratic Culture and the European Qualifications Passport for Refugees. $\mathrm{He}$ has represented the Council of Europe in the Bologna Follow Up Group and Board since 2000 and chaired three successive working groups on structural reforms 2007-15. Sjur is the editor of the Council of Europe Higher Education Series and was a main author of the Lisbon Recognition Convention.

Open Access This chapter is licensed under the terms of the Creative Commons Attribution 4.0 International License (http://creativecommons.org/licenses/by/4.0/), which permits use, sharing, adaptation, distribution and reproduction in any medium or format, as long as you give appropriate credit to the original author(s) and the source, provide a link to the Creative Commons license and indicate if changes were made.

The images or other third party material in this chapter are included in the chapter's Creative Commons license, unless indicated otherwise in a credit line to the material. If material is not included in the chapter's Creative Commons license and your intended use is not permitted by statutory regulation or exceeds the permitted use, you will need to obtain permission directly from the copyright holder.

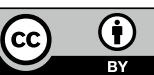

